\title{
Kontribusi Pendapatan Perempuan Terhadap Pendapatan Rumahtangga (Studi Pasar Sentral Majene Sulawesi Barat)
}

\author{
Dahlia \\ Dosen Program studi Akuntansi UNSULBAR \\ Email dahlia.fsmajene@gmail.com
}

\begin{abstract}
The purpose of this study was to determine the effect of female traders' income on household income in Majene Central Market, West Sulawesi. To determine the effect of female traders' income on household income in Majene Central Market, West Sulawesi, a simple linear regression test was conducted. The results showed that the income of female traders had a positive and significant effect on household income in Majene Central Sulawesi, West Sulawesi.
\end{abstract}

Keywords: Female Income, Household Income

\section{Latar Belakang}

Keterlibatan wanita dalam kerja produktif akan menimbulkan perubahan sosial, dikarenakan salah satu wujud perubahan sosial adalah perubahan dalam kerja. Masuknya wanita dalam pasar kerja atau kerja produktif berpengaruh terhadap kegiatan ekonomi rumah tangga, sehingga dapat terjadi perubahan struktur ekonomi keluarga (Wisadirana, 2004)

Adanya keinginan perempuan bekerja untuk mencari nafkah dalam meningkatkan kontribusi pendapatan dalam memenuhi kebutuhan sehari-hari keluarganya. Dimana mana wanita tergolong hanya aktif sebagai ibu rumah tangga yang mengurus suami, anak, maupun saudaranya akan tetapi fakta dilapangan justru wanita juga berperan aktif bekerja diluar rumah. Hal ini disebabkan karena rendahnya pendapatan suami dalam bekerja tentunya wanita juga berkontribusi membantu mencari nafkah agar kebutuhan keluarga terpenuhi.

Berdasarkan hasil observasi yang dilakukan di Pasar Sentral Kabupaten Majene dapat dilihat bahwa sangat banyak perempuan yang bekerja dan membantu suami dalam mencari nafkah, namun dalam kenyataannya pendapatan perempuan sering dianggap hanya sebagai pendapatan sampingan atau bukan pendapatan utama, padahal jika dilihat dari curahan waktu kerja dalam rumahtangga, perempuan lebih banyak mencurahkan waktu, karena di samping 
mengurus keluarga seperti memasak, mencuci, dan mengurus anak, perempuan masih harus membantu suami dengan bekerja atau mencari nafkah dalam rangka memenuhi kebutuhan rumahtangga.

Fenomena perempuan bekerja untuk mencari nafkah terjadi karena dorongan kebutuhan, kemauan dan kemampuan serta kesempatan kerja yang tersedia dan akses perempuan atas kesempatan tersebut. Dengan demikian peranan sektor informal menjadi penting terutama dalam kemampuan menyerap banyak tenaga kerja dan tidak menuntut tingkat keterampilan yang tinggi (Sukesi dan Sugiyanto dalam Priminingtyas, 2007).

Kontribusi perempuan terbagi atas tujuh bagian yang sebagian besar berorientasi ke dalam kontribusi keluarga (domestic role) dan selebihnya lebih berorientasi pada masyarakat luas (public role). Ketujuh kontribusi tersebut antara lain: (1) kontribusi sebagai orang tua (parental role), (2) kontribusi sebagai istri (conjugal role), (3) kontribusi di dalam rumahtangga (domestic role), (4) kontribusi di dalam kekerabatan (kin role), (5) kontribusi pribadi (individual role), (6) kontribusi di dalam masyarakat (community role), dan (7) kontribusi di dalam pekerjaan (occupational role). Pembahasan ini akan ditekankan pada kontribusi perempuan dalam pekerjaan di luar rumah atau yang lebih dikenal dengan sektor publik yang tentunya akan menghasilkan pendapatan berupa uang yang kemudian akan dikontribusikan kepada rumahtangganya (Oppong dan Chuch dalam Indrayati, 2011).

Kondisi Pasar sentral Majene saat ini cukup baik, pasar dibersihkan oleh petugas kebersihan pada pagi hari sebelum aktivitas berdagang dimulai dan sore hari setelah aktivitas berdagang selesai. Para pedagang berjualan pada tempat-tempat yang telah disediakan pemerintah Bagi para pedagang yang tidak dapat ditampung dalam bangunan pasar diijinkan berjualan di pinggir jalan. Semua pedagang diwajibkan membayar retribusi kepada pengelola pasar dan koperasi pasar. Sebagian besar pelaku usaha di Pasar Pasar sentral Majene adalah perempuan. Ada 253 orang pedagang yang 186 orang $(73,51 \%)$ diantaranya adalah perempuan. Aktivitas berjualan dimulai sejak pukul 05.00 WIT hingga sore hari sekitar pukul 19.00 WIT, namun tidak semua pedagang pulang pada pukul 19.00 WIT karena ditentukan apakah hasil dagangan habis terjual ataupun tidak. 
Berdasarkan latar belakang yang telah diuraikan maka peneliti tertarik melakukan penelitian dengan judul Kontribusi Pendapatan Perempuan Terhadap Pendapatan Rumahtangga (Studi Pasar Sentral Majene Sulawesi Barat)

\section{Tujuan Penelitian}

Tujuan dalam penelitian ini adalah untuk mengetahui pengaruh pendapatan perempuan pedagang terhadap pendapatan rumahtangga di Pasar Sentral Majene Sulawesi Barat

\section{Kajian Pustaka}

Penelitian terdahulu yang membahas topik yang sama dengan penelitian ini adalah :

1. Rohmiati Amini (2013) Judul penelitiannya yaitu Analisis dampak pemberdayaan wanita nelayan melalui program Usaha garam rakyat (pugar) terhadap kondisi ekonomi Keluarga Nelayan Di Kabupaten Lombok Barat. Hasil penelitiannya menunjukkan Hasil penelitian ini menunjukkan bahwa partisipasi wanita nelayan dalam PUGAR dapatmeningkatkan kondisi ekonomi keluarga nelayan.

2. Efendi Feriyansah (2015) judul penelitiannya Pengaruh pendapatan suami dan Pendapatan istri terhadap ekonomi Keluarga (Studi Kasus di PT. Pagilaran Unit Kaliboja), hasil penelitiannya menunjukkan pengaruh variabel pendapatan suami (X1) dan variabel pendapatan istri(X2) terhadap ekonomi keluarga $(\mathrm{Y})$ secara bersama-sama adalah positif dan signifikan.

3. Normina Br Perangin angindkk (2015) Judul penelitiannya yaitu Kontribusi Pekerja Perempuan Terhadap Pembentukan Pendapatan Keluarga. Hasil penelitiannya menunjukkan menunjukkanbahwa -rata pendapatanperempuan dalam studi ini masih sangat rendah, sehingga kontribusinyaterhadap pendapatan keluarga masih relatif rendah, hanya sebesar $36,23 \%$.

\section{Metode Penelitian}

1. Lokasi Penelitian

Penelitian ini dilaksanakan di Pasar Sentral Majene Sulawesi Barat, Pemilihan lokasi ini sesuai dengan tujuan penelitian, yaitu peneliti ingin mengetahui pengaruh pendapatan perempuan pedagang terhadap pendapatan rumahtangga di Pasar Sentral Majene Sulawesi Barat 
2. Populasi dan Sampel

a) Populasi

Populasi adalah wilayah generalisasi yang terdiri atas: obyek/ subyek yang mempunyai kualitas dan karakteristik tertentu yang ditetapkan oleh peneliti untuk dipelajari dan kemudian ditarik kesimpulannya.Populasi dalam penelitian ini adalah seluruh perempuan pedagangdi Pasar Sentral Majene Sulawesi Baratyang berjumlah 253 orang

b) Sampel

Sampel adalah bagian dari jumlah dan karakteristik yang dimiliki oleh populasi tersebut. Bila populasi besar, dan peneliti tidak mungkin mempelajari semua yang ada pada populasi. Sampel adalah pengambilan sebagian objek untuk diselidiki yang akan mewakili populasi.

Jika populasi kurang dari 100 orang, maka lebih baik diambil semua dalam penelitian, dan Selanjutnya jika populasinya besar, maka dapat diambil 10-15\%, 20-25\%, atau lebih.Dalam penelitian ini subyek atau responden yang dijadikan sampel mengambil $15 \%$ dari populasi, yaitu sebanyak 38 pedagang.

\section{Metode Pengumpulan Data}

Penelitian ini dilakukan di lapangan dan didukung dengan kajian membaca berbagai sumber kepustakaan, dan dalam mengumpulkan data-data yang dibutuhkan, penulis menggunakan metode sebagai berikut:

a) Angket

Angket adalah suatu daftar pertanyaan tentang topik tertentu, yang akan diberikan kepada objek atau baik secara individu atau kelompok untuk mendapatkan informasi tertentu.Angket ini digunakan untuk mengukur minat berwirausaha dan efektifitas pembelajaran mata kuliah kewirausahaan.

Dalam penelitian ini peneliti mengunakan skala likert. Skala ini menilai sikap atau tingkah laku yang diinginkan oleh para peneliti dengan cara mengajukan beberapa pertanyaan kepada responden. Kemudian responden diminta memberikan pilihan jawaban atau respons dalam skala ukur yang telah disediakan.Dalam penelitian ini pilihan jawaban dalam angket yaituSangat Setuju (SS) dengan skor 4, Setuju (S) dengan skor 3, Kurang Setuju (KS) dengan skor 2, Tidak Setuju (TS) dengan Skor 1. 


\section{An-Nisa', Volume XI Nomor 2 Desember 2018}

b) Wawancara

Wawancara atau interview merupakan suatu teknik pengumpulan data yang dilakukan secara tatap muka, pertanyaan diberikan secara lisan dan jawaban diterima secara lisan pula. Dalam menggunakan metode interview ini peneliti melakukan komunikasi langsung atau wawancara dengan kepala pasar sentral Majene dan para pedagang untuk mendapatkan keterangan yang peneliti butuhkan sebagai bahan untuk melengkapi data.

c) Dokumentasi

Dokumentasi adalah ditujukan untuk memperoleh data langsung dari tempat penelitian, meliputi buku yang relevan, peraturan-peraturan, laporan kegiatan, fotofoto, film dokumenter, data yang relevan penelitian.Metode dokumentasi ini digunakan untuk mengumpulkan data yang bersifat dokumen, misalnya: data jumlah pedagang, serta data lain yang mendukung penelitian ini.

\section{Teknik Analisis Data}

\section{Uji Normalitas}

Pengujian tentang kenormalan distribusi data. Penggunaan uji normalitas karena pada analisis statistik parametik, asumsi yang harus dimiliki oleh data adalah bahwa data tersebut harus terdistribusi secara normal, maksudnya adalah bahwa data akan mengikuti bentuk distribusi normal.

Uji normalitas bertujuan untuk menguji apakah dalam sebuah model regresi, variabel dependen dan variabel independen atau keduanya mempunyai dstribusi normal atau tidak. Jika data menyebar disekitar garis diagonal dan mengikuti arah garis diagonal maka model regresi memenuhi asumsi Normalitas. Selain itu Uji Normalitas bisa dilakukan dengan teknik Kolmogorov-Smirnov. Data yang berdistribusi normal adalah Sig. KolmogorovSmirnov hitung $>$ Sig. Penelitian (0,05). Dan Jika signifikansi Kolmogorov-Smirnov hitung yang diperoleh $<\alpha$, maka sampel bukan berasal dari populasi yang berdistribusi normal.

\section{Uji Koefisien Regresi}

Untuk mengetahui pengaruh pendapatan perempuan pedagang terhadap pendapatan rumahtangga di Pasar Sentral Majene Sulawesi Barat, dilakukan uji regresi linear sederhana. Model penelitian yang digunakan dalam penelitian ini adalah :

$$
\mathrm{Y}=\alpha+\beta \mathrm{X}+\mathrm{e}
$$

\section{Keterangan :}




$$
\begin{aligned}
\mathrm{Y} & =\text { Pendapatan Rumah Tangga } \\
\mathrm{X} & =\text { pendapatan perempuan pedagang } \\
\alpha & =\text { Intercept/Konstanta } \\
\beta & =\text { Parameter/koefisien regresi } \\
\mathrm{e} & =\text { Error terms }
\end{aligned}
$$

\section{Hasil Penelitian}

1. Pengaruh Pendapatan Perempuan Pedagang Terhadap Pendapatan Rumahtangga Di Pasar Sentral Majene Sulawesi Barat

Aktivitas berdagang sehari-hari pedagang perempuan dimulai sekitar pukul pukul 05.00 WIT, kemudian pada pukul 17.00 WITA, tidak semua responden melakukan aktivitas berdagang pada pukul 05.00-19.00 WITA. Hal ini tergantung pada hasil dagangan yang habis terjual ataupun tidak habis terjual seperti pedagang ikan. Sebagian dari pedagang ikan tersebut memilih untuk pulang ke rumah (rata-rata sekitar pukul 14.00 WITA) jika dagangan sudah habis terjual

\section{a. Uji Normalitas}

Berdasarkan hasil olah data dapat dilihat bahwa titik-titik menyebar disekitar garis dan mengikuti garis diagonal, sehingga dapat disimpulkan bahwa data yang digunakan dalam penelitian ini adalah berditribusi normal sehingga dapat dilanjutkan pada analisis regresi linear.

Gambar 3 Scotter Plot Uji Normalitas Data

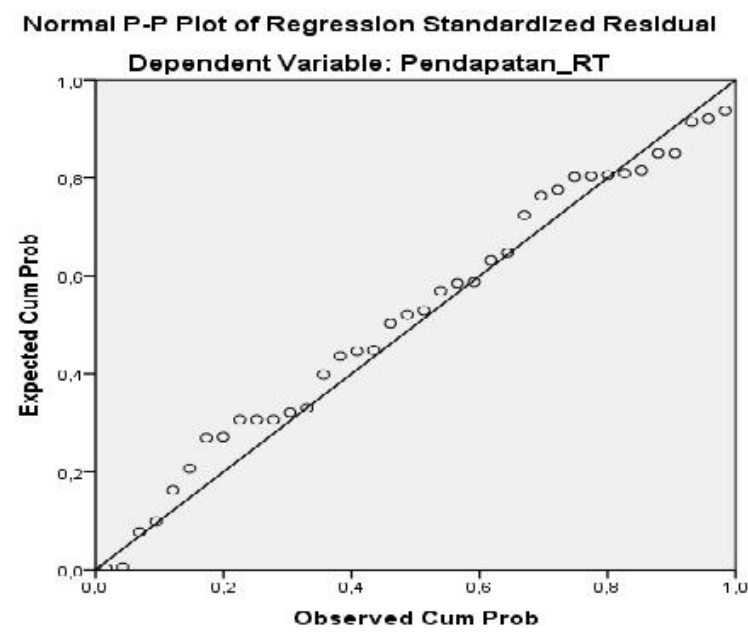

Sumber : Hasil olah data, 2018 
b. Uji regresi linear sederhana

Analisis regresi linear sederhana digunakan untuk mengetahui seberapa besar pengaruh pendapatan perempuan pedagang terhadap pendapatan rumahtangga di Pasar Sentral Majene Sulawesi Barat. Analisis regresi linear sederhana dalam penelitian ini menggunakan program SPSS yang dapat dilihat pada tabel 4.30 sebagai berikut:

Tabel. 3 Hasil Olah Data Regresi Linear Sederhana

\section{Coefficients $^{\mathrm{a}}$}

\begin{tabular}{|c|c|c|c|c|c|}
\hline \multirow[t]{2}{*}{ Model } & \multicolumn{2}{|c|}{$\begin{array}{c}\text { Unstandardized } \\
\text { Coefficients } \\
\end{array}$} & \multirow{2}{*}{\begin{tabular}{|c|}
$\begin{array}{c}\text { Standardized } \\
\text { Coefficients }\end{array}$ \\
Beta
\end{tabular}} & \multirow[t]{2}{*}{$\mathrm{t}$} & \multirow[t]{2}{*}{ Sig. } \\
\hline & B & $\begin{array}{l}\text { Std. } \\
\text { Error }\end{array}$ & & & \\
\hline (Constant) & ,588 & ,624 & & ,942 &, 353 \\
\hline $\begin{array}{ll}1 & \text { Pendapatan } \\
\text { Perempuan }\end{array}$ & ,883 &, 145 & ,713 & 6,103 &, 000 \\
\hline
\end{tabular}

a. Dependent Variable: Pendapatan_RT

Sumber : Hasil olah data, 2018

Berdasarkan hasil olah data tersebut persamaan dalam penelitian ini menjadi:

$$
Y=0,588+0.883+\varepsilon
$$

1) Nilai costanta sebesar 0,588

Jika tidak ada perubahan pada nilai variabel pendapatan perempuan pedagangmakapendapatan rumahtangga di Pasar Sentral Majene Sulawesi Baratsebesar 0,588

2) Nilai koefisien regresi variabel pendapatan perempuan pedagang sebesar 0,883

Nilai koefisien regresi variabel pendapatan perempuan pedagang sebesar0,883 menunjukkan bahwa jika variabel pendapatan perempuan pedagangnaik sebesar 1 maka pendapatan rumahtangga di Pasar Sentral Majene Sulawesi Barat akan naik sebesar 0,883. Dan sebaliknya variabel pendapatan perempuan pedagang sebesar turun sebesar 1 maka pendapatan rumahtangga di Pasar Sentral Majene Sulawesi Baratakan turun sebesar 0,883. Sehingga dapat disimpulkan pendapatan perempuan pedagang berpengaruh positif terhadap pendapatan rumahtangga di Pasar Sentral Majene Sulawesi Barat.

3) Nilai signifikansi sebesar 0,000 
Nilai signifikansi sebesar 0,000 menunjukkan bahwa variabel pendapatan perempuan pedagang berpengaruh signifikan terhadap motivasi pendapatan rumahtangga di Pasar Sentral Majene Sulawesi Barat.

2. Pembahasan

Berdasarkan hasil penelitian maka dapat disimpulkan bahwa pendapatan perempuan pedagangberpengaruh positif dan signifikan terhadap pendapatan rumahtangga di Pasar Sentral Majene Sulawesi Barat.

Kontribusi pendapatan dapat diartikan sebagai sumbangan pendapatan berupa uang yang diberikan perempuan yang bekerja kepada pendapatan. Kemudian dalam mengurus rumahtangga sekaligus membantu suami dalam menafkahi kebutuhan rumahtangga dapat membuat perempuan pedagang memiliki kebanggan tersendiri dan kepercayaan diri yang tinggi. Perempuan pedagang tidak hanya memperoleh tambahan secara finansial dan membantu dalam mengatasi kesulitan ekonomi rumahtangga saja, tetapi juga merupakan aktualisasi diri dalam kehidupan sosial. Berdagang ternyata dapat meningkatkan status perempuan, sebab dengan begitu perempuan memiliki kemampuan secara ekonomi dan memiliki kepercayaan diri karena meningkatnya andil perempuan dalam ekonomi rumah tangga

Hasil Penelitian ini sejalan dengan penelitian Randi Wilson Sahetapy dkk (2016) hasil penelitiannya menunjukkan pendapatan perempuan pedagang berkontribusi sebesar 71,65\%. Hasil penelitian ini juga sejalan dengan penelitian sofyan dkk dimana pendapatan perempuan berpengaruh positif dan signifikan terhadap pendapatan rumahtangga.

\section{Daftar Pustaka}

Adji, Wahyu., dkk. 2007.Ekonomi Jilid 2. Jakarta: Penerbit Erlangga.

Arikunto, Suharsimi, 2006, Metode Penelitian: Prosedur Penelitian Suatu Pendekatan Praktik, Jakarta : Rineka Cipta

Agus, Widarjono. 2013. Ekonometrika Pengantar Dan Aplikasinya. Jakarta.Ekonosia.

Bastian, Indra, 2011, Sistem Akuntansi Sektor Publik, penerbit salemba empat ,Jakarta

Diana Djuwita (2015) Peran Perempuan Masyarakat Pesisir dalam Meningkatkan Pendapatan Keluarga Nelayan di Desa Mertasinga. Jurnal Al Amwal IAIN Syekh Nurjati Cirebon. Horngren,et al. (2009), Akuntansi Edisi ketujuh. PT. Indeks Kelompok Gramedia. Jakarta. 


\section{An-Nisa', Volume XI Nomor 2 Desember 2018}

Indrayati A (2011) Kontribusi Wanita dalam pemberdayaan ekonomi lokal melalui preferensi ruang belanja. Jurnal Geografi

Priminingtyas, D. N. (2007) Analisis Sosial ekonomi perencanaan pedesaan didalam keluarga dan masyarakat. Jurnal Buana Sains

Randi Wilson Sahetapy dkk (2016) Kontribusi Pendaptan Perempuan Pedagang Terhadap Pendapatan Rymah Tangga Di Pasar Transit Negeri Passo Kecamatan Teluk Ambon Baguala Kota Ambon. Jurnal Agrilian

Roma Y. F. Hutapea, Abdul Kohar, dan Abdul Rosyid (2015) Peranan Wanita Nelayan (Istri Nelayan) Jaring Insang Dalam Meningkatkan Pendapatan Keluarga Di Desa Bejalen, Perairan Rawa Pening, Kecamatan Ambarawa, Kabupaten Semarang Journal of Fisheries Resources Utilization Management and Technology .

Ridwan. (2009). Metode \& Teknik Menyusun Proposal Penelitian. Jakarta : Alfabeta

Rohmiati Amini (2013) Analisis Dampak Pemberdayaan Wanita Nelayan Melalui Program Usaha Garam Rakyat (Pugar) Terhadap Kondisi Ekonomi Keluarga Nelayan Di Kabupaten Lombok Barat. Jurnal. GaneÇ Swara Vol. 7 No.2

Singarimbun, Masri dan Effendi, Sofian (Editor). 2011. Metode Penelitian Survay. Jakarta: PT Pustaka LP3ES Indonesia.

Soekartawi, 2006. Agribisnis Teori dan Aplikasi. Rajawali Press. Jakarta

Sugiono, 2008, Metodologi Penelitian kuantitatif, Kualitatif, dan $R \& D$, :Bandung.Alfabeta. 